\title{
Pemodelan Peningkatan Kualitas Air Sungai melalui Variasi Debit Suplesi
}

\author{
Arya Rezagama ${ }^{*}$, Anik Sarminingsih, Ajeng Yasinta Rahmadani, Afifah Nadya Aini \\ Departemen Teknik Lingkungan Fakultas Teknik, Universitas Diponegoro, \\ Jl. Prof. Soedarto, SH, Kampus UNDIP Tembalang, Semarang, Indonesia 50275
}

\begin{abstract}
Abstrak
Kualitas air sungai sangat dipengaruhi oleh besarnya debit yang mengalir serta kondisi kualitas air pada kawasan hulu. Sungai Pepe merupakan saluran penggelontor kota Surakarta yang diharapkan dapat difungsikan menjadi area wisata. Namun kualitas air Sungai tersebut termasuk dalam golongan IV atau tidak sesuai dengan peruntukannya. Limbah domestik dan industri UKM yang masuk ke sungai serta rendahnya baseflow sungai menjadi penyebabnya. Penelitian ini bertujuan untuk memodelkan kualitas air Sungai Pepe dengan melakukan variasi suplesi debit dari Sungai Anyar sehingga kualitas air Sungai Pepe menjadi lebih baik. Simulasi dilakukan dengan menggunakan model Qual2Kw. Pengukuran kualitas air eksisting dilakukan pada 6 titik pengambilan sampel. Variasi debit suplesi yang digunakan meliputi kondisi eksisting, suplesi $0,5 \mathrm{~m}^{3} / \mathrm{s}$ dan $1 \mathrm{~m}^{3} / \mathrm{s}$. Debit suplesi ke Sungai Pepe Hilir dapat di atur melalui pintu air di Sungai Anyar. Hasil penelitian menunjukkan bahwa semakin besar penambahan debit suplesi akan berbanding lurus dengan kualitas air sepanjang ruas sungai. Parameter DO dan COD membaik menunjukkan kemampuan areasi yang membaik akibat hidrodinamika aliran sungai.
\end{abstract}

Kata kunci: Debit; Kualitas Sungai; Model Qual2Kw

\begin{abstract}
[Title: Modeling Of Pepe River Quality with Variations in Debit Suplements] River water quality is influenced by the amount of flowing discharge and water quality conditions in the upstream area. Pepe River is a Surakarta city channel that is expected to function as a tourist area. But the water quality of the River is included in group IV or not according to its designation. Domestic waste and SME industries that enter the river and low river baseflow are the causes. This study aims to model the water quality of the Pepe River by varying the discharge of discharge from the Anyar River so that the water quality of the Pepe River becomes better. Simulation is done using the Qual2Kw model. Existing water quality measurements were carried out at 6 sampling points. The variation of the supple discharge used includes the existing conditions, supplying $0.5 \mathrm{~m} 3 / \mathrm{s}$ and $1 \mathrm{~m} 3 / \mathrm{s}$. Supply discharge to the Pepe Hilir River can be arranged through the sluice gate at Sungai Anyar. The results showed that the greater the addition of supletion discharge will be directly proportional to the quality of water along the river segment. Improved $D O$ and COD parameters show improved area capability due to hydrodynamics in river flows.
\end{abstract}

Keywords: Flow; River Quality; Qual2Kw Model

\section{Pendahuluan}

Kepadatan penduduk yang berkembang pesat mengakibatkan adanya penurunan kualitas air karena adanya limbah dari aktivitas manusia yang berasal dari kegiatan industri, pertanian, dan rumah tangga yang

\footnotetext{
${ }^{*}$ Penulis Korespondensi.

E-mail: arya_tl@ft.undip.ac.id
}

menghasilkan limbah (Agustiningsih \& Sasongko, 2006). Kualitas air sungai sangat dipengaruhi oleh besarnya debit yang mengalir serta kondisi kualitas air pada kawasan hulu. Sama halnya dengan sungai Pepe yang memiliki permasalahan pencemaran baik oleh limbah domestik maupun limbah UKM tekstil. Sungai Pepe merupakan salah satu sungai yang memiliki peran penting untuk kehidupan masyarakat di Kota Surakarta sebagai saluran pembuangan kota (Sundari, 2016). 


\section{TEKNIK, 40 (2), 2019, 107}

Kualitas air Sungai Pepe termasuk dalam kualitas air golongan IV yang mengandung Chemical Oxygen Demand (COD) dan Biological Oxygen Demand (BOD) yang cukup tinggi. Kandungan air tersebut disebabkan dari hasil limbah domestik dan industri yang langsung dibuang ke sungai (Widowati, Astuti, \& Rahayu, 2017).

Pada tahun 2015 Pemerintah Kota Surakarta meresmikan Sungai Pepe sebagai ikon sungai wisata melalui penataan bantaran (Widowati $d k k$., 2017). Berdasarkan Undang-Undang No 10 Tahun 2009 tentang Kepariwisataan, salah satu daya tarik wisata adalah keindahan, maka sebaiknya estetika Sungai Pepe perlu di perbaiki. Syarat kelas air sungai minimal yang harus dipenuhi pada sektor pariwisata adalah kelas dua berdsarakan Peraturan Pemerintah No 82 Tahun 2001 tentang pengelolaan kualitas air dan pengendalian pencemaran air.

Debit air yang mengalir berpengaruh terhadap kualitas air sungai. Pada saat musim kemarau dimana debit air yang mengalir melewati sungai relatif kecil akan memperburuk kualitas sungai (Priyana, 1994). Salah satu strategi dalam perbaikan kualitas air sungai ialah dengan memberikan debit tambahan/ suplesi dari bagian hulu. Peningkatan debit akan mengakibatkan pengenceran dari sumber pencemaran dan meningkatkan laju aliran. Penelitian yang ada saat ini lebih banyak di lakukan di negara lain, seperti pada Sungai Kshipira India dimana sumber pencemar yang masuk berasal dari limbah domestik dan industry (Gupta, Gupta, \& Shrivastava, 2014). Pada Sungai Pepe memiliki karakterisitik pencemaran limbah tekstil bercampur dengan limbah domestik.

Model kualitas air ini berguna untuk melihat perilaku kontaminan dan dampaknya pada kualitas air. Skenario simulasi berguna untuk mengetahui cara atau tindakan yang cepat dan tepat jika ada kontaminan (Antunes, Albuquerque, Oliveira, \& Sánz, 2018). Proyeksi pemodelan kualitas air penelitian ini menggunakan software Qual2Kw. Qual2Kw adalah model kualitas air sungai satu dimensi dan bersifat steady state (Pelletier, Chapra, \& Tao, 2006). Model Qual2Kw sudah digunakan di Sungai Bagmati, Nepal dan menghasilkan model yang mewakili data lapangan dengan cukup baik (Raj $d k k$., 2007). Di Malaysia model Qual2Kw digunakan untuk menentukan strategi pengelolaan yang tepat pada Sungai Tebrau (Zainudin, 2015). Qual2Kw membutuhkan parameter input yang sederhana, model ini juga sudah digunakan di Portugal sebagai alat manajemen kualitas air pada sungai kecil (Oliveira, Quinteiro, Nadais, \& Arroja, 2011). Secara umum, metode ini relatif sederhana dan ekonomis untuk menganalisa rasio kontribusi sumber polutan.

Penelitian ini bertujuan untuk memodelkan kualitas air Sungai Pepe dengan melakukan variasi suplesi debit sehingga kualitas air Sungai Pepe dapat diperbaiki. Pengaturan suplesi dari hulu sungai dapat digunakan sebagai alternatif menejemen sumber daya air.

\section{Metode Penelitian}

Penelitian ini dilaksanakan pada tahun 2017. Lokasi penelitian di Sungai Pepe Hilir, Kota Surakarta. Pengambilan sampel dilaksanakan pada bulan Juli hingga Agustus 2017. Peralatan dalam pengambilan sampel antara lain botol sampel, label, water sampler, dan alat tulis. Metode pengambilan contoh atau sampling yang dipakai dalam penelitian ini adalah metode pengambilan contoh sesaat (Grab sampel).

Metode penentuan debit pada penelitian ini menggunakan metode pengukuran langsung di lapangan dan menggunakan data hasil studi literature dari Laporan Hidrologi Dinas Lingkungan Hidup Kota Surakarta. Analisa kualitas air dan variasi suplesi debit menggunakan pemodelan. Pemodelan kualitas air menggunakan software Qual2Kw. Pemodelan Qual2Kw adalah metode pemodelan kualitas air yang dikembangkan oleh USEPA (United States Environmental Protection Agency). Software Qual2Kw dapat digunakan untuk sungai yang berukuran kecil maupun besar (Hossain, Sujaul, \& Nasly, 2014). Qual2Kw dapat mensimulasikan dan menyederhanakan kondisi kualitas air pada suatu sungai yang nantinya disajikan dalam bentuk grafik. Neraca massa yang digunakan dalam Qual2Kw terlihat pada Persamaan 1 (Pelletier $d k k$., 2006).

$$
\begin{aligned}
\frac{d C i}{d t}=\frac{Q_{i-1}}{V i} C_{i-1} & -\frac{Q 1}{V i} C_{i}-\frac{Q_{a b, i}}{V i} C i+\frac{E_{i-1}}{V i}\left(C_{i-1}-C_{i}\right) \\
& +\frac{E_{i}}{V i}\left(C_{i+1}-C_{i}\right)+\frac{W_{i}}{V i}+S
\end{aligned}
$$

Dimana Qi adalah Debit (m3/s), ab adalah abstraksi, Vi adalah volume (m3), Ei' adalah koefisien dispersi massal antara reach i dan i $+1(\mathrm{~m} 3 / \mathrm{d})$, Wi adalah external loading parameter di reach i $(\mathrm{g} / \mathrm{d}), \mathrm{Si}$ adalah bertambah dan berkurangnya konstituen karena reaksi dan mekanisme transfer massa $\mathrm{g} / \mathrm{m} 3 / \mathrm{d}$ ) dan $\mathrm{Ci}$ adalah konsentrasi konstituen.

Validasi model dilakukan dengan metode Mean Relative Error (MRE). Metode ini digunakan untuk mengetahui kemiripan data lapangan dengan model yang dihasilkan (Zaman \& Syafrudin, 2007). Model dianggap valid jika nilai MRE kurang dari $10 \%$ (Setiawan, Widyastuti, \& Hadi, 2018).

$$
\operatorname{MRE}=\frac{|\boldsymbol{X}-\boldsymbol{C}|}{\boldsymbol{X}} \times 100 \%
$$

Dimana MRE adalah Mean Relative Error, C adalah nilai simulasi dan $\mathrm{X}$ adalah nilai actual. 


\section{TEKNIK, 40 (2), 2019, 108}

Penelitian ini dimulai dengan melakukan pengamatan parameter pencemar Sungai Pepe Hilir. Penelitian ini dibagi menjadi 5 segmen. Pengujian kualitas air di Sungai Pepe Hilir, dilakukan pada 6 titik sepanjang Sungai Pepe Hilir dan pada point source yang masuk sesuai pada gambar 1. Anak sungai yang masuk ke Sungai Pepe Hilir dianggap sebagai point source. Selain itu juga dilakukan pengamatan terhadap point source dan non point source yang masuk ke Sungai Pepe Hilir. Point source adalah sumber pencemar yang berasal dari pipa pembuangan, parit, dll (Setiawan $d k k$., 2018).

Point source mencakup pembuangan limbah kota, UKM dan air limbah industri (Wu \& Chen, 2013). Sumber data point source berasal dari dokumen data yang dimiliki Dinas Lingkungan Hidup Kota Surakarta. Non point source adalah pencemar yang terbawa melalui air limpasan, sehingga tidak dapat di deteksi secara pasti sumber dari pencemar tersebut. Sehingga sumber non point source lebih sulit untuk diukur dan diatur (Effendi, 2003). Sumber pencemaran non point source diidentifikasi berdasarkan survei lapangan di sepanjang aliran sungai.

\section{Kualitas Air Sungai Pepe Hilir}

Parameter kualitas air hasil sampling dibandingkan dengan baku mutu PP No 82 Tahun 2001 untuk mengetahui kelas air Sungai Pepe Hilir. Hasil sampling kualitas air dapat dilihat pada Tabel 1. Parameter DO untuk titik PI 4, PI 6 dan PI 5 masuk kedalam kelas II, PI 1 masuk kedalam kelas III, sedangkan PI 3 dan PI 2 masuk kedalam kelas IV. Parameter COD titik PI 6 masuk kedalam kelas II, sedangkan kelima titik yang lain masuk kedalam baku mutu kelas IV. Parameter nitrat pada semua titik telah melebihi baku mutu kelas IV. Hasil pengamatan menunjukkan bahwa dari hulu ke hilir konsentrasi pencemar semakin buruk. Hal ini sesuai dengan penelitian sebelumnya yang menunjukkan kualitas air semakin buruk dari hulu hingga ke hilir (Rosiana, Handayani, \& Qomariah, 2016). Skematik hasil ujikualitas ai rdapat dilihat pada gambar 2 meliputi sungai dan 4 anak sungai lainnya.

Tabel 1. Hasil Pengujian Kualitas Air Sungai Pepe Hilir

\begin{tabular}{lrrrrrr}
\hline Para & \multicolumn{6}{c}{ Kode Sample (mg/L) } \\
\cline { 2 - 7 } meter & \multicolumn{1}{c}{ PI 6 } & \multicolumn{1}{c}{ PI 5 } & \multicolumn{1}{c}{ PI 4 } & \multicolumn{1}{c}{ PI 3 } & \multicolumn{1}{c}{ PI 2 } & \multicolumn{1}{c}{ PI 1 } \\
\hline Suhu & 28.5 & 28.9 & 29.1 & 30.1 & 29.7 & 29.2 \\
pH & 7.84 & 7.23 & 7.61 & 7.49 & 7.47 & 7.09 \\
DO & 5,8 & 5,9 & 4.9 & 2.2 & 1.2 & 3.80 \\
COD & 20.5 & 81.4 & 108.9 & 102.7 & 168 & 54.79 \\
Nitrat & 26,95 & 24.85 & 20.3 & 24.5 & 21.5 & 26.80 \\
\hline
\end{tabular}

\section{Hasil dan Pembahasan \\ Morfologi Sungai Pepe Hilir}

Sungai Pepe hilir keseluruhan masuk dalam kota Surakarta seperti pada gambar 1 dan 2 yang menerima suplesi dari sungai pepe hulu. Sungai Pepe Hilir memiliki penampang sungai yang sempit dan dalam. Sungai Pepe Hilir memiliki panjang 5.670 meter, lebar atas 6-40 meter, lebar bawah 5-32 meter, dan kedalaman 5-10 meter. Kondisi morfologi dan aliran Sungai Pepe Hilir sebagian sudah tertata dengan baik serta penetrasi matahari cukup baik. Namun debit yang kecil dibandingkan beban pencemaran yang masuk menyebabkan proses purifikasi tidak mampu menguraikan limbah yang masuk. Debit sungai pepe hilir sangat dipengaruhi oleh pintu air di bendung tirtonadi di sungai Anyar. Pada saat pengambilan sampel, pintu air tersebut di tutup sehingga tidak ada limpasan dari Kali Anyar yang masuk ke Sungai Pepe.

\section{Debit Andalan}

Tahun 2016 memiliki karakteristik tahun basah dimana curah hujan yang turun dengan intensitas tinggi terjadi hampir di semua bulan. Berdasarkan gambar 4 menunjukkan hubungan antara Sungai Anyar dan Pepe hilir dimana terdapat Bendung Tirtonadi yang mengatur buangan serta pintu air yang dapat di atur untuk memasukkan air ke Sungai Pepe Hilir. Hasil pengukuran debit pada tahun 2016 dalam Studi Daya tampung Kota Surakarta, puncak musim penghujan terjadi pada bulan Februari dengan debit sebesar $18,11 \mathrm{~m}^{3} /$ detik dan puncak musim kemarau terjadi pada bulan AgustusSeptember dengan debit sebesar 1,54 m3/detik. Maka dengan adanya debit ini, dapat dialihkan untuk mensuplai sungai Pepe hilir bahkan di musim kemarau.

Keberadaan debit Kali Pepe hanya ada pada bulan Februari, Maret dan April sehingga kegiatan wisata tersebut tidak dapat dijalankan secara maksimal setiap waktu. Menurut analisis model HEC-RAS yang dilakukan oleh Balai Besar Wilayah Sungai (BBWS) Bengawan Solo Kota Surakarta, kegiatan wisata perahu dapat dilaksanakan dengan adanya debit sungai minimal 6m3/detik. Dengan demikian, secara kualitas air Kali Pepe dalam kategori tidak siap untuk dikembangkan wisata. Debit terkecil yang mengalir DAS Pepe Hilir berkisar 0,11 m3/detik pada bulan September dan debit banjir terbesar 12,09 m3/detik pada bulan Juni. 
TEKNIK, 40 (2), 2019, 109

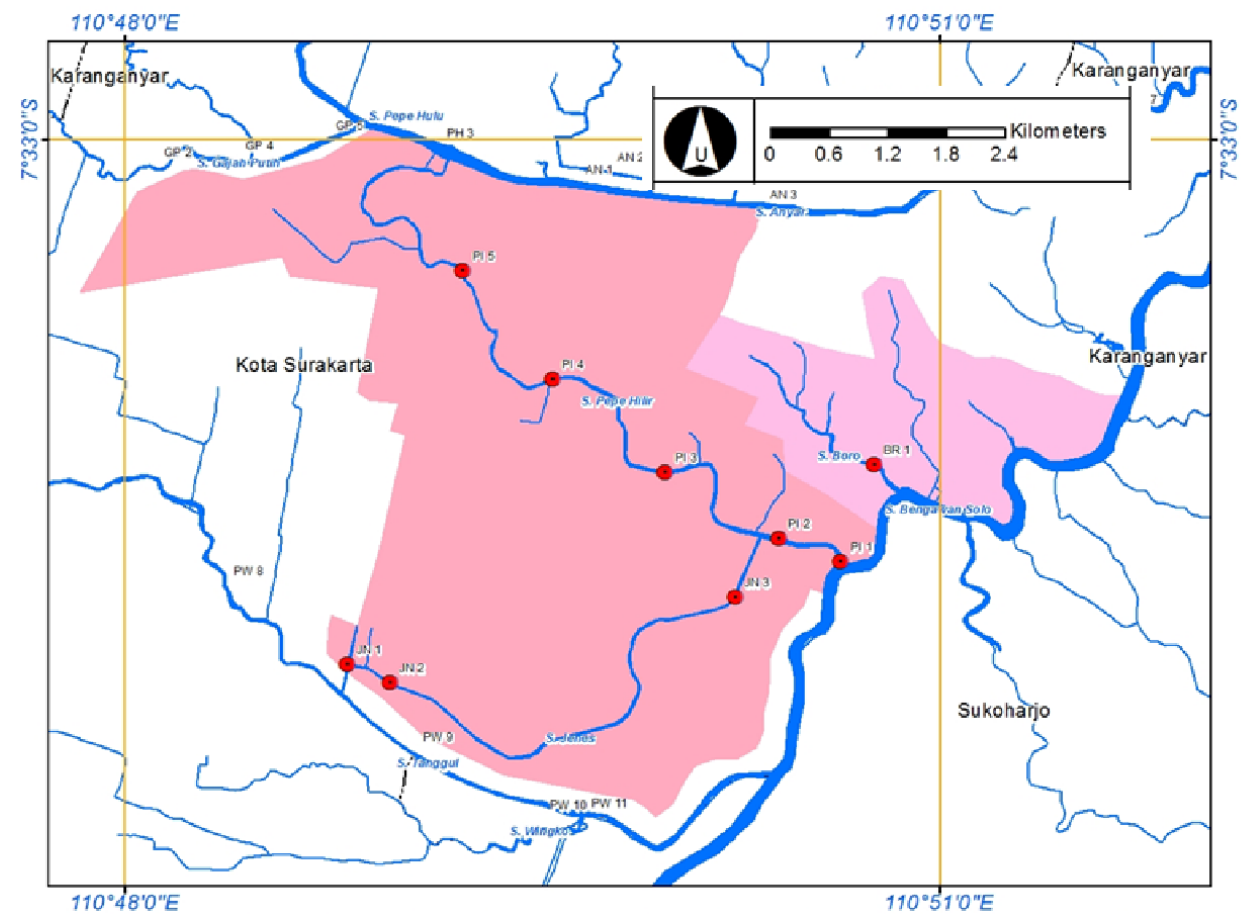

Gambar 1. Lokasi Titik Sampling Sungai Pepe Hilir

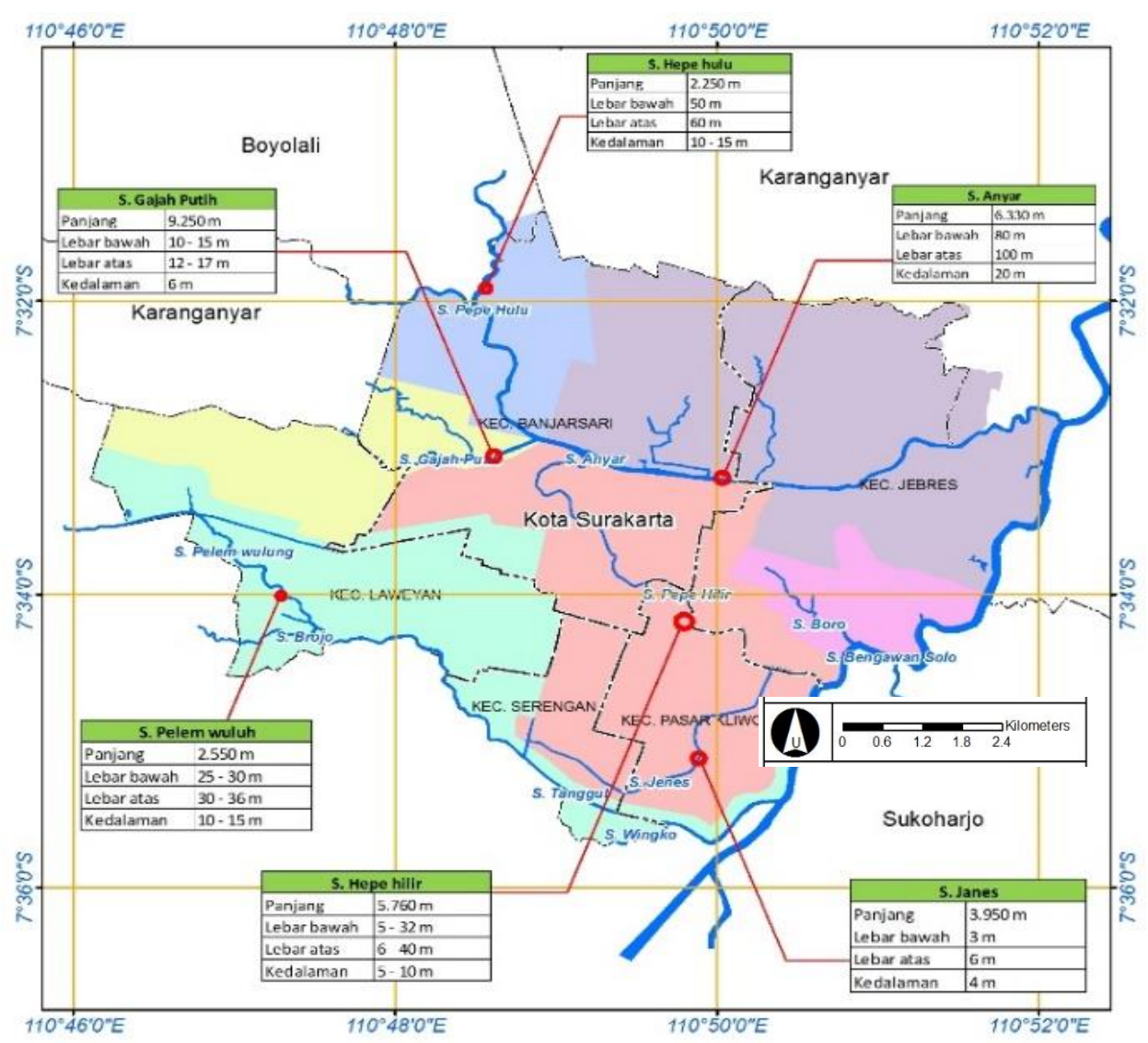

Gambar 2. Hubungan Aliran Sungai di Kota Surakarta 


\section{TEKNIK, 40 (2), 2019, 110}

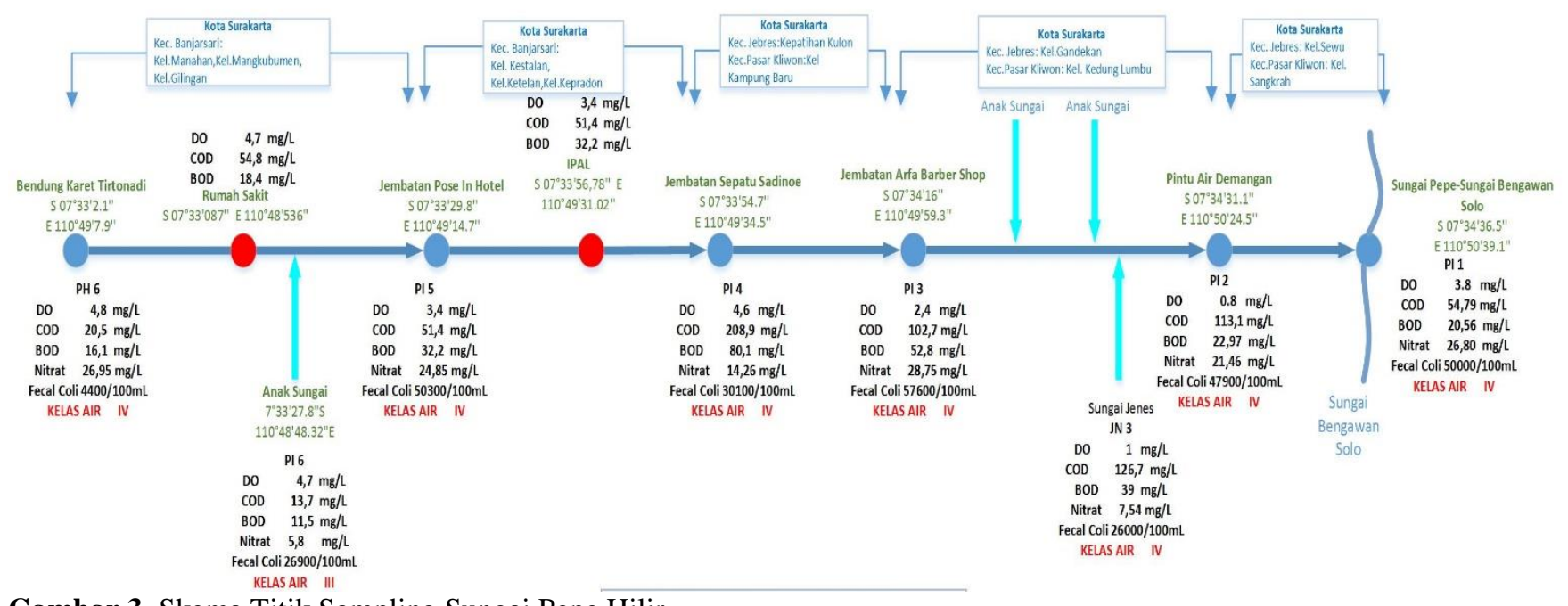

Gambar 3. Skema Titik Sampling Sungai Pepe Hilir

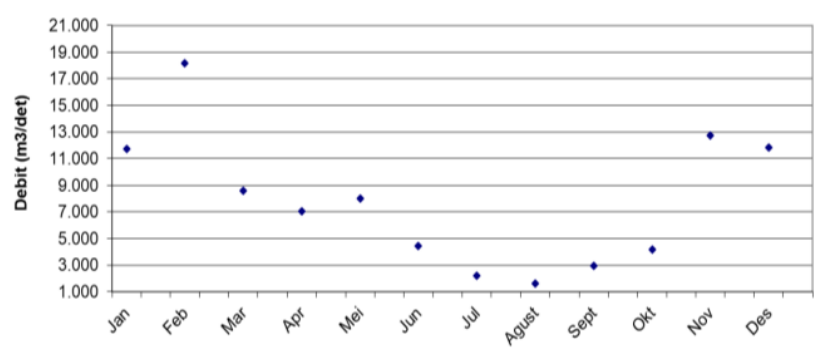

Gambar 4. Prakiraan Debit di Sungai Anyar yang digunakan untk suplesi Sungai Pepe

Sumber : Dinas Lingkungan Hidup Kota Surakarta 2017

Hasil perhitungan selanjutnya yaitu rerata debit andalan bulanan. Puncak musim penghujan terjadi pada bulan Februari dan November. Sedangkan puncak musim kemarau terjadi pada bulan Juli-Agustus. Besarnya debit andalan pada puncak musim penghujan sebesar 2,77 m3/detik pada bulan Februari dan 2,03 m3/detik pada bulan November untuk tingkat kepercayaan 50\%. Besarnya debit andalan pada puncak musim kemarau bulan Agustus adalah 0,12 m3/detik untuk tingkat kepercayaan 50\%. Kebutuhan akan suplesi air pada musim kemarau menjadi penting dalam perbaikan kualitas air.

\section{Hasil Pemodelan Eksisting}

Pengukuran debit pada hulu Sungai Pepe Hilir yaitu di Bendung Tirtonadi sebesar 0,07 m3/s. Gambar 5 menunjukkan bahwa debit meningkat dari hulu ke hilir, hal ini disebabkan karena adanya masukan dari Diffuse source sepanjang sungai. Gambar 3 menunjukkan bahwa terdapat 3 anak sungai yang masuk ke dalam Sungai
Pepe dan satu anak sungai Jenes yang memiliki nilai kualitas air cukup buruk.

Gambar 6 menunjukkan bahwa parameter DO dari hulu ke hilir semakin menurun. Pada bagian hilir, DO kurang dari $4 \mathrm{mg} / \mathrm{l}$ sehingga tidak memenuhi baku mutu kelas II. DO menurun secara signifikan pada jarak 2,5 $\mathrm{km}$ dari hilir dikarenakan adanya masukan dari Sungai Jenes, dimana sepanjang Sungai Jenes terdapat UKM Batik yang berpotensi mencemari air sungai. Nilai DO dapat meningkat disebabkan oleh turbulensi air, dan sedikitnya polusi organik. Perubahan kualitas air pada anak sungai jenes sangat tergantung pada buangan air limbah yang masuk. Pada saat UKM memmbuang sisa air rendaman batik, maka seketika air sungai dapat berubah warna secara signifikan tergantung dari jenis pewarna yang digunakan. Sebaliknya nilai DO rendah dapat disebabkan karena turbulensi air yang rendah dan banyaknya polusi organik yang masuk kedalam sungai (Kannel \& Lee, 2007).

Hasil pemodelan eksisting untuk parameter COD pada gambar 7 menunjukkan hasil nilai COD semakin meningkat dari hulu ke hilir. Hal tersebut dikarenakan adanya masukan dari IPAL, rumah sakit, anak sungai, dan pembuangan limbah dari permukiman sekitar. Selain dari limbah IPAL, kualitas air sungai dapat memburuk dengan berbagai beban pencemaran yang tidak terkendali dari daerah pemukiman (Hur \& Cho, 2012). Penataan ruang memiliki korelasi yang signifikan terhadap beban pencemar yang masuk ke sungai (Rezagama, Laila, Nadya, \& Lia Setiawati, 2018). Sungai Jenes membuat COD naik secara signifikan. Parameter COD masih melebihi baku mutu kelas II sebesar $25 \mathrm{mg} / \mathrm{l}$. 


\section{TEKNIK, 40 (2), 2019, 111}

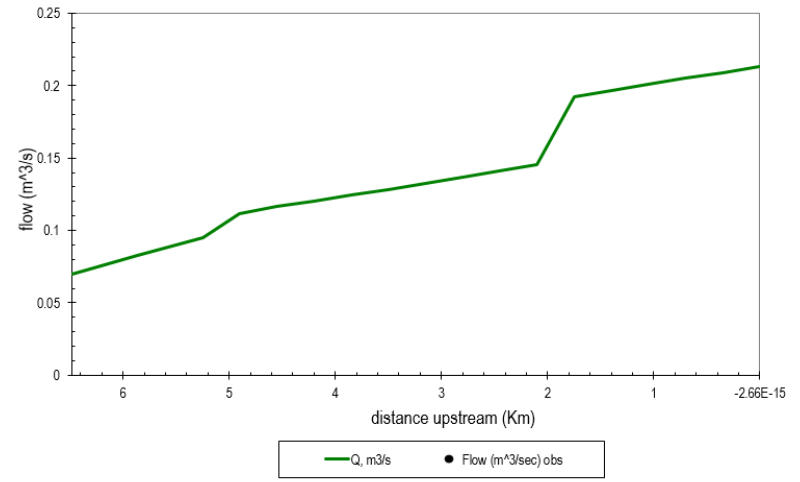

Gambar 5. Hasil Pemodelan Debit Eksisting

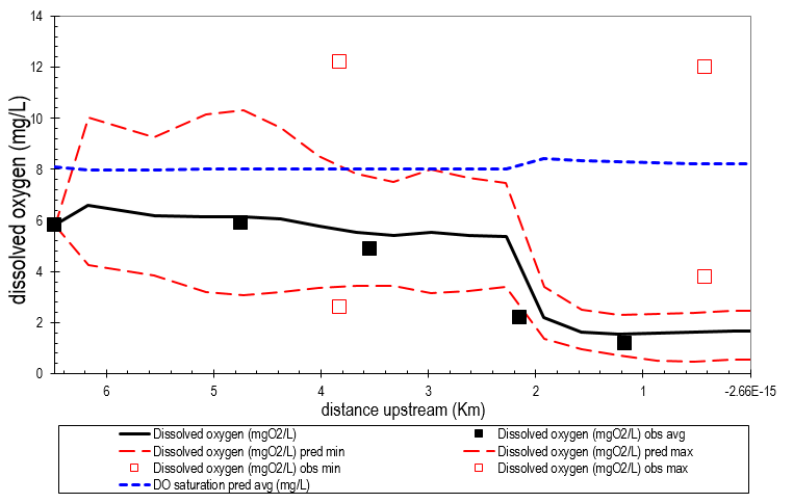

Gambar 6. Hasil Pemodelan DO Eksisting

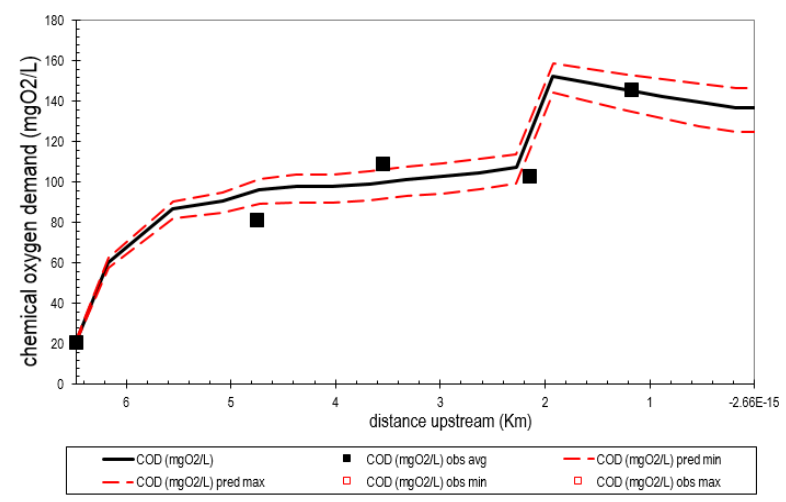

Gambar 7. Hasil Pemodelan COD Eksisting

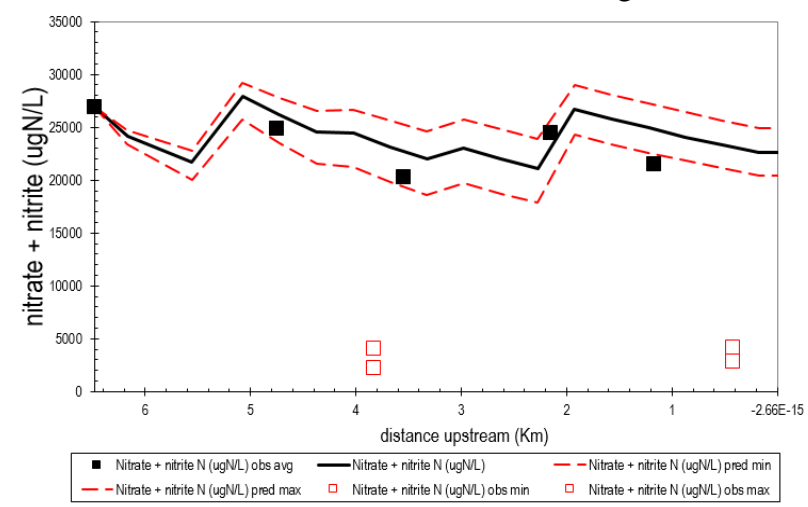

Gambar 8. Hasil Pemodelan Nitrat Eksisting
Perbedaan terlihat pada parameter nitrat, dimana dari hulu ke hilir mengalami penurunan. Nilai nitrat seperti pada gambar 8 masih melebihi baku mutu kelas II yang ditetapkan pada PP No 82 Tahun 2001 yaitu sebesar $10 \mathrm{mg} / \mathrm{l}$. Secara alamiah, kadar nitrat biasanya agak rendah, namun kadar nitrat dapat menjadi tinggi pada air tanah di daerah yang diberi pupuk dan mengandung nitrat (Alaerts \& Santika, 1987). Validasi menggunakan perhitungan MRE pada tabel 2 menunujukkan nilai MRE yang relatif rendah. atau model semakin valid. Nilai MRE dibawah 10\% menunjukkan hasil yang valid. Hasil MRE untuk parameter DO, COD, dan nitrat semua masih dibawah 10\%. Pada segmen 3 dan 5 terdapat validasi yang kurang baik, di mana terjadi hasil yang fluktuatif berdasarkan data yang di dapat dari sampling di lapangan. Sedangkan pada segmen 1,2 dan 4 nilai validasinya cukup baik. Secara rata-rata nilai keseluruhan masuk dalam rentoang eroro $10 \%$.

\section{Pemodelan Variasi Debit}

Pemodelan menggunakan variasi debit sebesar 0,5 $\mathrm{m}^{3} / \mathrm{s}$ dan $1 \mathrm{~m}^{3} / \mathrm{s}$ berdasarkan debit yang tersedia di Kali Anyar sebesar $1,54 \mathrm{~m}^{3} / \mathrm{s}$ di musim kemarau. Penambahan debit terjadi pada bagian hulu karena letak Kali Anyar sebagai sumber suplai debit terletak di hulu Sungai Pepe Hilir tepatnya di Jembatan Tirtonadi.

Hasil simulasi suplesi debit untuk parameter DO terdapat pada gambar 9. Dari hasil pemodelan yang ditunjukan dengan garis hitam menunjukkan bahwa pada debit $1 \mathrm{~m} 3 / \mathrm{s}$ nilai DO semakin meningkat, sehingga memenuhi baku mutu kelas II yaitu minimal 4 $\mathrm{mg} / \mathrm{l}$. Perbedaan pada debit $1 \mathrm{~m} 3 / \mathrm{s}$ terlihat jelas pada bagian hilir sungai, jarak antara baku mutu minimal dengan model semakin jauh dibandingkan dengan debit $0,5 \mathrm{~m} 3 / \mathrm{s}$, hal ini menandakan bahwa kualitas air semakin baik. Semakin besar debit yang mengalir maka semakin baik pula sistem purifikasi yang terjadi.

Pada pencampuran dengan Sungai Jenes nampak nilai DO turun signifikan, nilai COD juga naik pada interval yang tinggi. Buangan limbah batik dari sungai jenes yang masuk ke sungai pepe mempengaruhi secara signifikan kualitas sungaim menjadi lebih buruk. Pengendalian kualitas air sungai jenes perlu dilakukan dengan tegas melalui pnegndalian pencemaran non point souce dari UKM batik yang masuk ke sungai.

Gambar 10 menunjukkan hasil simulasi suplesi debit untuk parameter COD bahwa pada debit $1 \mathrm{~m} 3 / \mathrm{s}$ tren nilai COD semakin menurun terhadap jarak, namun masih belum memenuhi baku mutu kelas II yaitu sebesar $25 \mathrm{mg} / \mathrm{l}$. Hal ini di karenakan juga kualitas air suplesi dari Sungai Anyar juga telah masuk dalam kelas tiga. Hasil pemodelan pada debit $1 \mathrm{~m} 3 / \mathrm{s}$ di bandingkan dengan debit $0,5 \mathrm{~m} 3 / \mathrm{s}$ nampak lebih baik terlihat dari jarak $6 \mathrm{~km}$ sampai ke hilir.

doi: 10.14710/teknik.v40n2.23893 


\section{TEKNIK, 40 (1), 2019, 112}

Tabel 2. Hasil Validasi MRE

\begin{tabular}{lccccccccc}
\hline Segmen & \multicolumn{4}{c}{ Data Lapangan } & \multicolumn{3}{c}{ Data Model } & \multicolumn{3}{c}{ Mre (\%) } \\
& DO & COD & Nitrat & DO & COD & Nitrat & DO & COD & Nitrat \\
\hline Segmen 1 & 5.80 & 20.5 & 26.95 & 5.80 & 20.5 & 26.95 & 0.00 & 0.00 & 0.00 \\
Segmen 2 & 5.90 & 81.40 & 24.85 & 6.16 & 96.24 & 26.15 & 4.45 & 18.23 & 5.22 \\
Segmen 3 & 4.90 & 108.90 & 20.26 & 5.55 & 99.19 & 23.15 & 13.31 & 8.91 & 14.29 \\
Segmen 4 & 2.20 & 102.70 & 24.45 & 2.19 & 107.23 & 21.08 & 0.45 & 4.41 & 13.78 \\
Segmen 5 & 1.20 & 168.00 & 21.46 & 1.54 & 145.73 & 24.93 & 28.58 & 13.25 & 16.17 \\
& \multicolumn{4}{c}{ Rata-Rata MRE } & & & & 9.36 & 8.96 \\
\hline
\end{tabular}

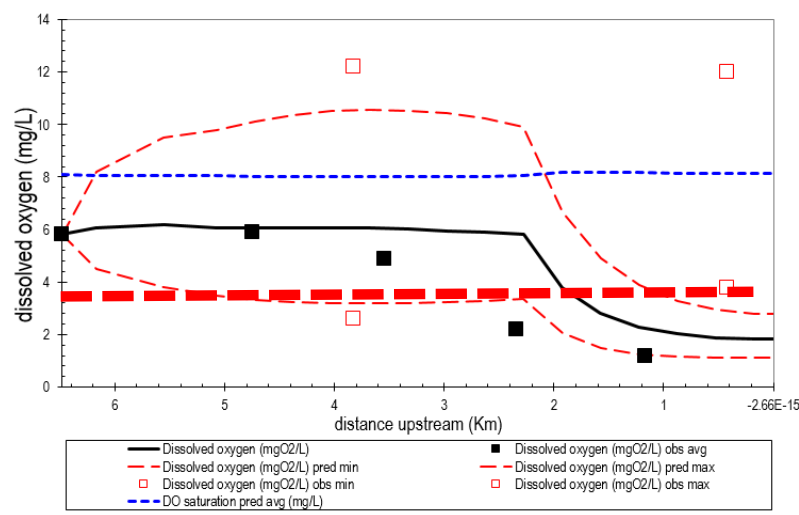

DO $0,5 \mathrm{~m}^{3} / \mathrm{s}$

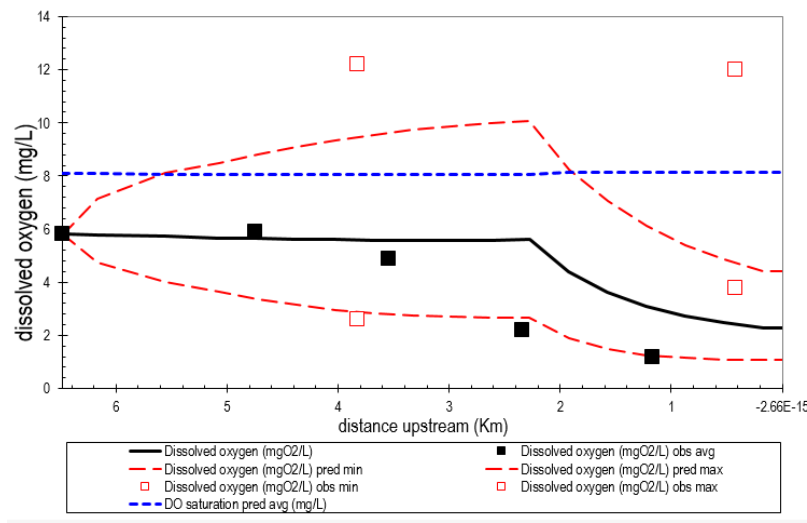

DO $1 \mathrm{~m}^{3} / \mathrm{s}$

Gambar 9. Hasil Pemodelan DO

Penambahan debit air sungai juga meningkatkan hidrodinamika air sehingga dapat meninkatkan kadar DO. Penambahan debit ini selain dapat memperbaiki parameter kimia kualitas air, diharapkan dapat meningkatkan nilai estetika Sungai Pepe Hilir. Semakin besar debit yang mengalir maka semakin baik pula sistem purifikasi yang terjadi.
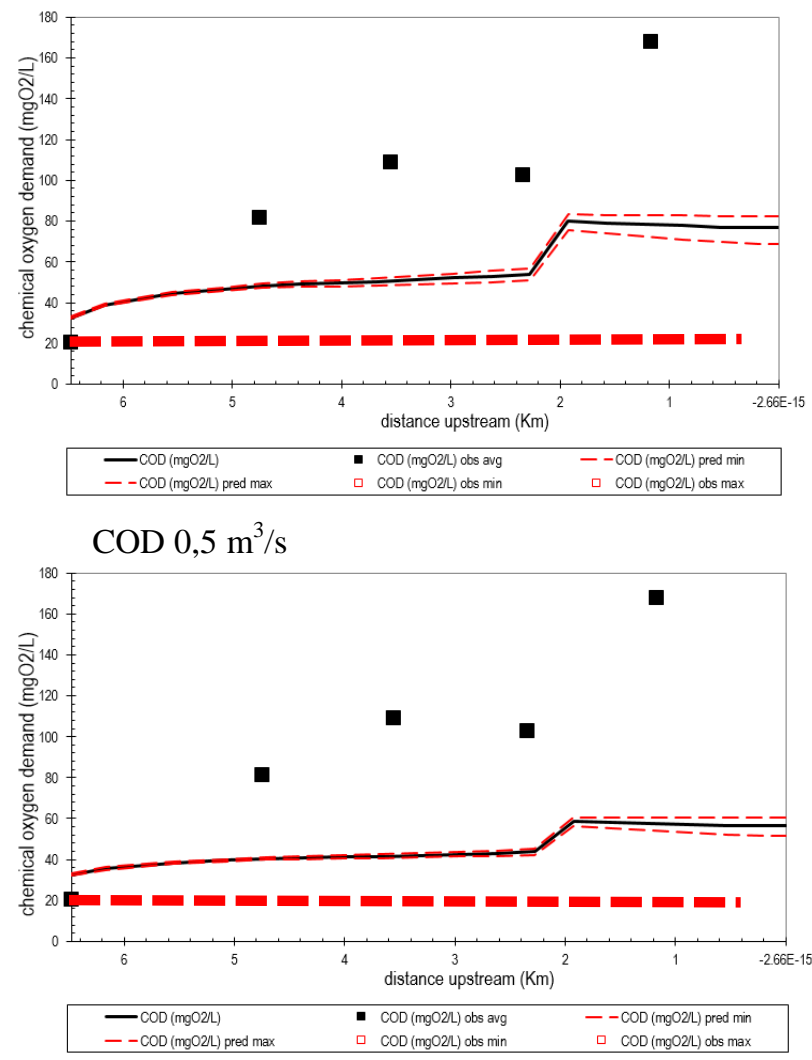

COD $1 \mathrm{~m}^{3} / \mathrm{s}$

Gambar 10. Hasil Pemodelan COD

Parameter kualitas air yang diamati berikutnya adalah parameter nitrat sperti ditunjukkan Gambar 11 . Berbeda dengan parameter DO dan COD, pada parameter nitrat berlaku sebaliknya. Penambahan debit air menyebabkan kualitas air semakin turun. Pada hasil pemodelan debit $1 \mathrm{~m}^{3} / \mathrm{s}$, jarak baku mutu dengan hasil pemodelan semakin jauh dibandingkan dengan debit 0,5 $\mathrm{m}^{3} / \mathrm{s}$. Baku mutu untuk parameter nitrat pada kelas II sebesar $10 \mathrm{mg} / \mathrm{l}$ atau $10.000 \mathrm{ug} / \mathrm{l}$. Hal ini menandakan bahwa kualitas air semakin menurun. 


\section{TEKNIK, 40 (2), 2019, 113}

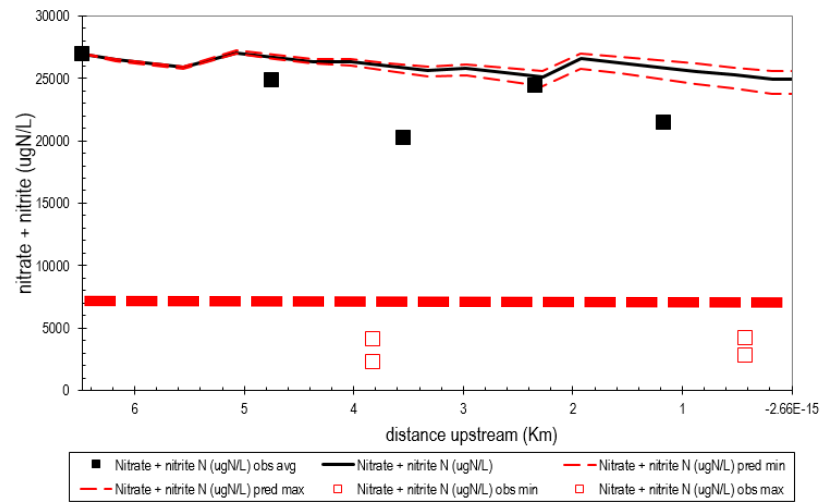

Nitrat $0,5 \mathrm{~m}^{3} / \mathrm{s}$

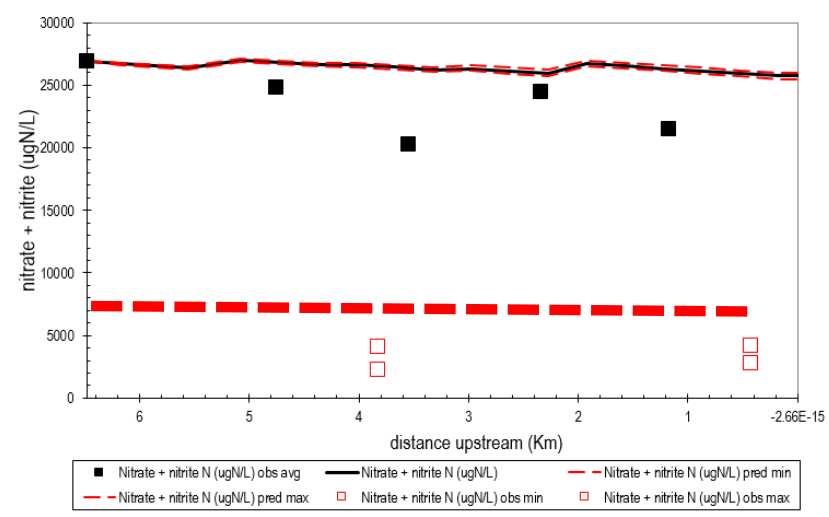

Nitrat $1 \mathrm{~m}^{3} / \mathrm{s}$

Gambar 11. Hasil Pemodelan Nitrat

\section{Kesimpulan}

Kualitas eksisting air Sungai Pepe Hilir untuk parameter DO, COD, dan Nitrat sebagian besar masuk kedalam baku mutu Kelas IV pada PP No 82 tahun 2001. Hasil pemodelan menunjukkan bahwa variasi suplesi belum dapat memperbaiki kualitasi air hingga masuk ke kelas 2. Penambahan debit air dari Sungai anyar ke Sungai Pepe Hilir meningkatkan kualitas air sungai untuk parameter DO dan COD tapi menurunkan kualitas air untuk parameter Nitrat. Penggunan model Qual2Kw dalam memprediksi kondisi esksting kualitas air Sungai Pepe hilir memiliki nilai validasi yang cukup baik. Adanya suplesi debit dari Sungai Anyar akan menyebabkan pengeceran terhadap pencemaran yang masuk ke dalam sungai. Pada debit $1 \mathrm{~m}^{3} /$ detik kualitas air dari Sungai Anyar mempu memperbaiki parameter di Sungai Pepe Hilir. Penambahan debit air sungai meningkatkan hidrodinamika air sehingga dapat meningkatkan kadar DO. Penambahan debit air selain memperbaiki parameter kimia kualitas air, diharapkan dapat meningkatkan nilai estetika Sungai Pepe Hilir. Semakin besar debit yang mengalir maka semakin baik pula sistem purifikasi yang terjadi. Di sisi lain penambahan debit air dari Sungai Jenes menurunkan kualitas air Sungai Pepe Hilir secara signifikan. Nilai DO turun drastis dan nilai COD naik pada interval yang tinggi. Ini disebabkan oleh buangan limbah batik dari Sungai Jenes.

\section{Ucapan Terimakasih}

Penulis juga mengucapkan terimakasih kepada Lembaga Penelitian dan Pengabidan Masyarakat Universitas Diponegoro atas dana penelitian skema Riset Pengembangan \& Penerapan (RPP) Tahun Anggaran 2019 dengan kontrak No. 474-40/UN7.P4.3/PP2019 dan Dinas Lingkungan Hidap Kota Surakarta, Badan Perencanan Pembangunan Dinas Kota Surakarta atas dukungan data serta masyarakat kota surakarta.

\section{Daftar Pustaka}

Agustiningsih, D., \& Sasongko, S. B. (2006). Analisis Kualitas Air Dan Strategi Pengendalian Pencemaran Air Sungai Blukar Kabupaten Kendal. Jurnal Presipitasi, 9(2), 64-71.

Alaerts, G., \& Santika. (1987). Metode Penelitian Air. Surabaya: Usaha Nasional.

Antunes, I. M. H. R., Albuquerque, M. T. D., Oliveira, S. F., \& Sánz, G. (2018). Catena Predictive scenarios for surface water quality simulation - A watershed case study. Catena, 170(February), 283-289.

https://doi.org/10.1016/j.catena.2018.06.021

Dinas Lingkungan Hidup (DLH) Kota Surakarta. (2017). Laporan Akhir Studi Kajian Daya Dukung Daya Tampung Beban Pencemaran Sungai di Kota Surakarta. Surakarta: DLH

Effendi, H. (2003). Telaah Kualitas Air. Yogyakarta: Kanisius.

Gupta, R. C., Gupta, A. K., \& Shrivastava, R. K. (2014). Water Quality Management of River Kshipra ( India ). International Journal of Environment Science, 5(2), 438-446. https://doi.org/10.6088/ijes.2014050100038

Hossain, M. A., Sujaul, I. M., \& Nasly, M. A. (2014). Application of QUAL2Kw for water quality modeling in the Tunggak River ,. Research Journal of Recent Sciences, 3(6), 6-14.

Hur, J., \& Cho, J. (2012). Prediction of BOD, COD, and Total Nitrogen Concentrations in a Typical Urban River Using a Fluorescence Excitation-Emission Matrix with PARAFAC and UV Absorption Indices. Sensors, 12, 972-986. https://doi.org/10.3390/s120100972

Kannel, P. R., \& Lee, S. (2007). Application of Water Quality Indices and Dissolved Oxygen as Indicators for River Water Classification and 


\section{TEKNIK, 40 (2), 2019, 114}

Urban Impact Assessment. Environ Monit Assess, 132, 93-110. https://doi.org/10.1007/s10661-0069505-1

Oliveira, B., Quinteiro, P., Nadais, M. H., \& Arroja, L. (2011). Application of Qual2Kw model as a tool for water quality management : Certima River as a case study. Environ Monit Assess, 184, 61976210. https://doi.org/10.1007/s10661-011-2413-z

Pelletier, G. J., Chapra, S. C., \& Tao, H. (2006). QUAL2Kw e A framework for modeling water quality in streams and rivers using a genetic algorithm for calibration, 21, 419-425. https://doi.org/10.1016/j.envsoft.2005.07.002

Priyana, Y. (1994). Masalah Sumberdaya Air Sungai di Pulau Jawa. Forum Geografi, (14), 64-73.

Raj, P., Lee, S., Lee, Y., Kanel, S. R., Pelletier, G. J., \& Box, P. O. (2007). Application of automated QUAL2Kw for water quality modeling and management in the Bagmati River, Nepal. Ecological Modelling, 2, 503-517. https://doi.org/10.1016/j.ecolmodel.2006.12.033

Rezagama, A., Laila, A., Nadya, A., \& Lia Setiawati. (2018). Pemodelan Beban Pencemar Non-Point Source Sungai Premulung Segmen Kota Surakarta. Presipitasi, 15(1), 36-45.

Rosiana, R., Handayani, F. S., \& Qomariah, S. (2016). Strategi pengendalian pencemaran air sungai pepe. Matriks Teknik Sipil, (2011), 562-569.
Setiawan, A. D., Widyastuti, M., \& Hadi, M. P. (2018). Water Quality Modeling for Pollutant Carrying Capacity Assess- ment using Qual2Kw in Bedog River. Indonesian Journal of Geography, 50(1).

Sundari, P. P. K. (2016). Identifikasi Fitoplankton di Perairan Sungai Pepe Sebagai Salah Satu Anak Sungai Bengawan Solo di Jawa Tengah. Seminar Nasional Pendidikan Dan Saintek, 1006-1011.

Widowati, N., Astuti, W., \& Rahayu, M. J. (2017). Tingkat Kesiapan Kali Pepe Untuk Dikembangkan Sebagai Kawasan Wisata Berbasis Sungai di Kota Surakarta. Arsitektura, 15(1), 67-75.

Wu, Y., \& Chen, J. (2013). Investigating the effects of point source and nonpoint source pollution on the water quality of the East River (Dongjiang ) in South China. Ecological Indicators, 32, 294-304. https://doi.org/10.1016/j.ecolind.2013.04.002

Zainudin, Z. (2015). Development of water quality model for Sg. Tebrau using QUAL2K. Journal of Applied Sciences, 10(21), 2748-2750.

Zaman, B., \& Syafrudin. (2007). Model Numerik 2-D (Lateral \& Longitudinal) Sebaran Polutan Cadmium(Cd) Di Muara Sungai (Studi Kasus: Muara Sungai Babon, Semarang). Jurnal Presipitasi, 3(2), 1-8. 